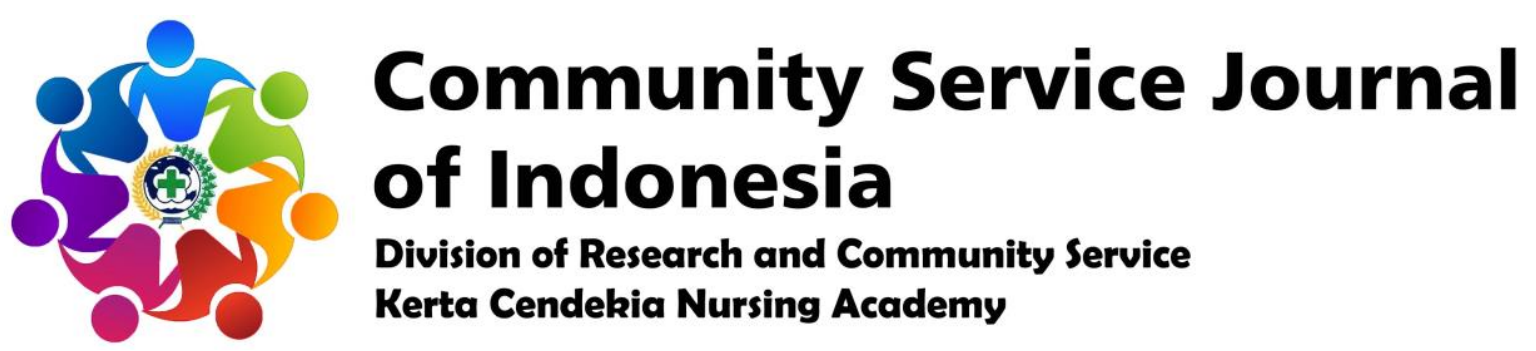

https://ejournal-kertacendekia.id/index.php/csji/index

Community Service Journal of Indonesia 1 (1) (2019): 14-17

Doi: https://doi.org/10.36720/csji.v1i1.68

\title{
IMPROVED KNOWLEDGE OF YOUNG GIRL ABOUT MENARCHE IN THE RANGKAH KIDUL ELEMENTARY SCHOOL, RANGKAH KIDUL VILLAGE, SIDOARJO SUB- DISTRICT, SIDOARJO DISTRICT, EAST JAVA PROVINCE
}

\author{
Riesmiyatiningdyah $^{1}$, Connie Wahyu Wijianti ${ }^{2}$, Sinta Nuriyah $^{2}$, Lidia Getreda Masela ${ }^{2}$, \\ Dwi Setyowati Rahayu², Muhammad Mughni Maulana², Meita Yusti Anugrah Sari², \\ Arina Rifatur Rizqya ${ }^{2}$ \\ ${ }^{1}$ Lecturer of Kerta Cendekia Nursing Academy, Sidoarjo \\ ${ }^{2}$ Student of Kerta Cendekia Nursing Academy, Sidoarjo
}

\begin{abstract}
Improved knowledge of young girl about menarche in the Rangkah Kidul Elementary School, Rangkah Kidul Village, Sidoarjo Sub-District, Sidoarjo District, East Java Province is a form of education in the form of counseling aimed at growing and increasing knowledge related to menarche. The activity was held on November 27, 2018 at the Rangkah Kidul Elementary School, Rangkah Kidul Village, Sidoarjo Sub-District, Sidoarjo District, East Java Province. With the goal is a $5^{\text {th }}$ grade student at the Rangkah Kidul Elementary School, Rangkah Kidul Village, Sidoarjo Sub-District, Sidoarjo District, East Java Province. Before the implementation of these activities, there is a process of preparing activities for 3 weeks before the activities are carried out, starting from the selection of health counseling materials to the submission of permits to related parties. As an evaluation, the event was attended by 18 participants who were $5^{\text {th }}$ grade students, participants took part in the activity enthusiastically and conductively, the activities could be carried out on time smoothly.
\end{abstract}

Keywords: Menarche, adolescent, health promotion, elementary school.

\section{INTRODUCTION}

Menarche is the first menstruation that usually occurs in the age range of 10-16 years or in the early teens in the middle of puberty before entering the reproductive period. Menstruation is periodic and cyclic bleeding from the uterus accompanied by endometrial exfoliation. Menarche is an early sign of other changes such as breast growth, pubic and axillary hair growth, and 
fat distribution in the hip region. During this time some people feel taboo to discuss menstrual problems in the family, so that early adolescents lack knowledge and attitudes that are quite good about physical and psychological changes related to menarche. Mental readiness is needed before menarche because of feelings of anxiety and fear of emergence, besides, also a lack of knowledge about self-care needed during menstruation (Proverawati \& Misaroh, 2009).

The age to reach the phase of menarche is influenced by factors such as ethnicity, genetics, social, economic, and others. In the UK the average reach of menarche is 13 years. In Indonesia teenage girls during menarche vary between $10-16$ years and the average menarche is 12.5 years. The age of menarche in urban areas is more sought after for those who live in the village and also for slower women who work hard (Wiknjosastro, 2003). From several studies since the last 100 years, it has been shown that there is a tendency for the teenagers to experience menarche more quickly. The decrease in age of menarche is due to improvements in nutrition, health services, and the community environment (Notoatmodjo, 2007).

In preventing and reducing the potential concern for children in dealing with the first menstruation, it is necessary to provide knowledge to the child so that the child is ready to face the first menstruation. Things that can be done include establishing a program for children such as counseling to recognize menarche, where the program will help children be better prepared to face menarche.

\section{OBJECTIVES}

General Purpose

After the activity is done, it is expected that all $5^{\text {th }}$ grade students of the Rangkah Kidul Elementary School, Rangkah Kidul Village, Sidoarjo Sub-District, Sidoarjo District, East Java Province will be able to understand more about menarche.

\section{Special Purpose}

After taking health promotion measures, it is expected that the students of the Rangkah Kidul Elementary School, Rangkah Kidul Village, Sidoarjo SubDistrict, Sidoarjo District, East Java Province can:

1. Mention the meaning of menarche.

2. Mention the signs and symptoms of menarche.

3. Mention factors that affect menarche.

\section{PLAN OF ACTION}

Strategy Plan

The strategy plan implemented, including:

1. Coordinate with the principal of the Rangkah Kidul Elementary School, Rangkah Kidul Village, Sidoarjo SubDistrict, Sidoarjo District, East Java Province to apply for permission to carry out health education or counseling as an activity of the nursing program and to help provide guidance to the students of the Rangkah Kidul Elementary School, Rangkah Kidul Village, Sidoarjo Sub-District, Sidoarjo District, East Java Province.

2. Establish students in the implementation of health education or counseling to know about menarche.

3. Contract time with the students of the Rangkah Kidul Elementary School, Rangkah Kidul Village, Sidoarjo Sub- 
District, Sidoarjo District, East Java Province.

4. Provide health promotion menarche.

\section{Implementation}

Actions taken in the implementation of these activities, including:

1. Contacted the principal of the Rangkah Kidul Elementary School, Rangkah Kidul Village, Sidoarjo Sub-District, Sidoarjo District, East Java Province to request permission for activities and gather the students of the Rangkah Kidul Elementary School, Rangkah Kidul Village, Sidoarjo Sub-District, Sidoarjo District, East Java Province.

2. Prepare a place and counseling media.

3. The students of the Rangkah Kidul Elementary School, Rangkah Kidul Village, Sidoarjo Sub-District, Sidoarjo District, East Java Province received extension materials.

\section{Setting}

This activity was carried out at the Rangkah Kidul Elementary School, Rangkah Kidul Village, Sidoarjo SubDistrict, Sidoarjo District, East Java Province.

\section{Target}

Target in this activity is all $5^{\text {th }}$ grade students of the Rangkah Kidul Elementary School, Rangkah Kidul Village, Sidoarjo Sub-District, Sidoarjo District, East Java Province.

\section{RESULTS AND DISCUSSION}

The activity is carried out on November 27, 2018 at 07.30 - 10.50 WIB in the classroom of the Rangkah Kidul Elementary School, Rangkah Kidul Village, Sidoarjo Sub-District, Sidoarjo District, East Java Province, this schedule is according to what has been determined. The equipment used during the discussion was laptops, power-points, videos, and leaflets. The use of communicative and applicative language in the delivery of health education, students respond quite well to what has been delivered by the presenter. The participants of this health promotion were 18 female students from the $5^{\text {th }}$ grade in the Rangkah Kidul Elementary School, Rangkah Kidul Village, Sidoarjo Sub-District, Sidoarjo District, East Java Province. Teachers at the Rangkah Kidul Elementary School, Rangkah Kidul Village, Sidoarjo SubDistrict, Sidoarjo District, East Java Province were very enthusiastic and worked very well together during the counseling. The participants who attended seemed enthusiastic to take part in counseling from the beginning to the end. Questions asked by participants can be answered well by presenters and teams. Based on the results of the final evaluation it was found that as many as $75 \%$ of participants could mention the notion of menarche, $90 \%$ of participants could mention the age of menarche, $85 \%$ of participants could influence menarche and change that coincided with menarche, and $80 \%$ of participants could take counseling material well.

\section{CONCLUSION}

Improved knowledge of young girl about menarche in the Rangkah Kidul Elementary School, Rangkah Kidul Village, Sidoarjo Sub-District, Sidoarjo District, East Java Province was considered quite successful because $75 \%$ of participants could mention the notion of menarche, $90 \%$ of participants could mention the age of menarche, $85 \%$ of participants could influence menarche and 
change that coincided with menarche, and $80 \%$ of participants could take counseling material well.

\section{REFERENCES}

Aryal, T. R. (2004). Age at menarche: differentials and determinants. Journal of the Nepal Medical Association, 43(152).

Hinchliff, S. (1999). Kamus keperawatan. Jakarta: EGC.

Manuaba, I. B. G. (2001). Kapita selekta penatalaksanaan rutin obstetri, ginekologi, dan KB. Jakarta: EGC.

Notoatmodjo, S. (2007). Promosi kesehatan dan ilmu perilaku. Jakarta: Rineka Cipta.

Prawirohardjo, S. (1999). Keluarga Berencana Dalam Ilmu Kebidanan. Jakarta: Yayasan Bina Pustaka.

Proverawati, A., \& Misaroh, S. (2009). Menarche menstruasi pertama penuh makna. Yogyakarta: Nuha Medika.

Wiknjosastro. (2003). Ilmu Kandungan. Jakarta: Yayasan Bina Pustaka Sarwono Prawirohardjo. 